\title{
Design of Fermentation Liquid Mixer of Coffee Beans
}

\author{
Warji Warji, Tamrin Tamrin, Sapto Kuncoro, Bambang Joko Sudarsan \\ Department of Agricultural Engineering, Faculty of Agriculture, Lampung University. Jl. Prof. \\ Dr. Ir. Soemantri Brojonegoro No. 1, Bandar Lampung, Indonesia. \\ Email: warji1978@gmail.com
}

\begin{abstract}
Indonesia is one of the fourth largest coffee producers in the world. Arabica and Robusta coffee are types of coffee that are quite widely grown in Indonesia. Both types of coffee are partly grown organically; namely coffee whose entire cultivation process does not involve chemicals such as pesticides or fertilizers derived from chemicals. Organic coffee can be processed into coffee that has a distinctive taste. The coffee processing process is now very modern and has various processes and stages. The coffee processing process is also influenced by the characteristics of each coffee company, wet and dry processes. One method of processing coffee is through a fermentation process by adding bio ghally. To mix the solution, a mixer is needed. Coffee bean mixing equipment with bio ghally liquid fermentation liquid is a tool in the stages of the coffee bean processing process to assist the process of mixing and wetting coffee beans with bio ghally liquid prior to the fermentation stage. The purpose of this research is to design and manufacture a coffee bean mixer of bio ghally fermented solution. This tool is designed to mix coffee beans with fermented liquid with a capacity of $25 \mathrm{~kg}$ and within 15 minutes. Machine parts include the frame, hoper,
\end{abstract}


mixing tube, drive motor and transmission. The results of the testing process for this coffee bean mixer show that the process of mixing $25 \mathrm{~kg}$ of coffee beans took 15,17 minutes.

Keywords: bio ghally, coffee beans, mixer.

\section{Introduction}

Coffee is one of the most widely grown crops by farmers in Indonesia; Indonesia ranks fourth in the world for producing coffee. Coffee plant varieties are divided into 3, namely Arabica, Robusta, and Liberica. Arabica and Robusta coffee are types of coffee that are quite widely grown in Indonesia. The area of coffee production in Indonesia is estimated at around 1.3 million hectares, which is spread over Sumatra, Java and Sulawesi. Robusta coffee is generally grown by farmers in South Sumatra, Lampung, and East Java, while Arabica coffee is generally grown by farmers in Aceh, North Sumatra, South Sulawesi, Bali, and Flores. Robusta coffee is a coffee that has a higher production when compared with Arabica coffee (Martauli, 2018). Indonesia's position is considered quite strategic in the international coffee world by having various types of coffee. Specialty coffee which has been widely known in the international market, including Gayo Coffee, Mandailing Coffee, Toraja Coffee, Kolasi Coffee, Java Coffee, Bali Kintamani Coffee, Flores Bajawa Coffee and Baliem Arabica Coffeea are types of coffee that are quite famous in the world (Swiranata et al., 2020). In addition to these of coffee, in Indonesia also developed another type of coffee, namely Luwak coffee. Luwak coffee is a type of coffee that has been processed through a short fermentation in the digestive tract of civet animals (Paradoxurus hermaphroditus). Enzymes in the digestive tract are able to produce coffee with a distinctive taste and aroma.

Coffee processing is an advanced process carried out to make coffee beans into food and beverage ingredients with the coffee variant. Today's coffee processing process is very modern and has various processes and stages, as it is known that the coffee processing process is also influenced by the times and market demand and is increasing. The application of semiwet processing technology in post-harvest coffee is one of the efforts to improve coffee 
quality. Fermented coffee cherries are thought to improve the taste of coffee (Cortez and Menezez, 2000).

The quality in producing coffee is determined by the processing, generally coffee is processed dry because the processing costs are lower than the wet processing (Sembiring et al., 2015). Meanwhile, the wet processing produces better quality coffee than the dry processing. Wet processing of coffee is carried out by large plantations, resulting in good physical quality of coffee, but in the fermentation process there is a risk of damage to the taste (Mayrowani, 2013); other than that it can improve the quality (Siregar et al., 2020; Usman et al., 2015). Wet processing is useful for breaking down the mucilage layer on coffee beans faster so that they are easy to clean, while eliminating microorganisms that exist on the surface (Thalia et al., 2018). One way to maintain and even improve the taste is by adding a bio ghally fermenter. Bio ghally fermentation liquid is a fermented liquid that uses ghally microbes which function to ferment coffee beans so that it produces a decrease in the caffeine content of coffee beans.

Gally organic coffee is organic coffee that all processes from the beginning such as preplanting to post-harvest use ghally organic technology. Gally organic coffee is the best coffee from ghally products because this coffee uses $100 \%$ organic ingredients that utilize ghally compounds to make coffee one of the best organic coffees in Lampung. Coffee "Ghalkoff" only uses $100 \%$ Lampung Fine Robusta coffee beans from plantations in West Lampung. This coffee uses fermentation technology, namely by using microorganism enzymes that can improve the quality of coffee. The coffee beans used as the main raw material for Ghalkoff coffee are coffee beans whose skin color is red or is said to be red pick. It is hoped that by using super quality coffee beans (Figure 1.) or red picks, quality coffee beans are obtained.

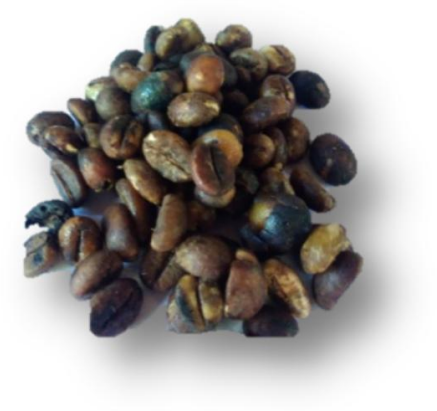

Figure 1. Coffee beans 
One method of processing organic coffee is fermentation by adding bio ghally. The mixer is needed to mix the bio ghally solution. Coffee bean mixing equipment with bio ghally liquid fermentation liquid is a tool in the stages of the coffee bean processing process to assist the process of mixing and wetting coffee beans with bio ghally liquid prior to the fermentation stage.

The purpose of this research is to design and manufacture a mixer of coffee bean with bio ghally liquid. The coffee bean mixer with bio ghally fermented liquid is designed with a working capacity of $25 \mathrm{~kg} /$ minute.

\section{Materials and Methods}

\subsection{Material and Tools}

The tools used in this study include the AutoCAD program, iron cutting machine, electric arc welding, smoothing grinder, cutting grinder, hammer, iron ruler, meter, angle ruler, calipers and iron bending tool. The materials used in the design process as well as the manufacture of this coffee bean mixing tool include a motor, glue, aquarium pump machine, drum tube, pipe iron, water hose, sprayer, elbow iron, plate iron, stirrup iron, pulley, v-belt, nuts, bolts, electrodes and coffee beans.

The coffee bean mixer with bio ghally fermentation liquid consists of a frame, mixing tube, hoper, pulley and v-belt, electric motor, mini water pump machine, and a tube for storing fermented liquid (Figure 2). The frame is made of sturdy mild steel with dimensions of the frame height is $1.5 \mathrm{~m}$, width is $78 \mathrm{~cm}$, and length is $1.5 \mathrm{~m}$.

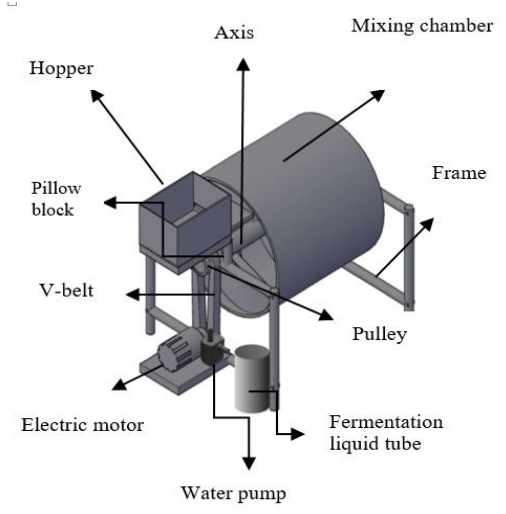

Figure 2. Design of a coffee bean mixer 


\subsection{Structural and Functional Design}

The components of the mixing tube are made of plastic tubes. This component functions as a container for coffee beans and fermented liquid as well as a place for mixing coffee beans with fermented liquid. The shaft is made of steel with a length of $1.5 \mathrm{~m}$ (adjusting to the length and dimensions of the frame) with a diameter of $4.8 \mathrm{~mm}$, serves as the rotating axis of the mixing tube. Pulley and v-belt, pulley uses cast iron base material with 5 inch and 2 inch diameter, while v-belt uses rubber base material. This component functions as a power transmitter from the electric motor. The driving force is a $1 \mathrm{HP}$ electric motor with $1420 \mathrm{rpm}$, the electric motor component serves as the main source of propulsion. Mini electric water pump machine, this component uses a mini electric water pump with high pressure, functions as a tool for pumping and spraying fermented liquid (bio ghally).

The sprayer, made of plastic or brass, functions as a sprayer that sprays the fermented liquid onto the material into smaller particles and is equipped with a spray discharge regulator. The fermentation liquid storage tube, made of 10 litres tube material, functions as a reservoir for the bio ghally fermented liquid. Pillow block, made of cast iron steel, serves as a bearing or support for the shaft so that the shaft can rotate and not be separated from the frame. Hopper, made of iron plate material with a length of $5-7.5 \mathrm{~cm}$ and a width of $4-5 \mathrm{~cm}$. This component serves as the material input channel into the mixing tube.

The coffee bean mixer works by rotating a drum or tube mixing coffee beans with bio ghally fermented liquid with the main power source from an electric motor engine. The power from the electric motor is transmitted through pulleys and v-belts and then the shaft is able to rotate the mixing tube. The coffee beans used use dry organic coffee beans which are the result of the plantation of PT Ghally Roelies Indonesia in West Lampung. The dried coffee beans used were $10 \mathrm{~kg}, 15 \mathrm{~kg}$ and $25 \mathrm{~kg}$. The dried coffee beans are put into the mixing tube via the input channel/hopper and then closed and the tube is rotated using an electric motor for 15 minutes. The length of the work process depends on the volume of the coffee beans being mixed, the fewer coffee beans $<10 \mathrm{~kg}$, the faster the mixing time, but the more coffee beans $15-25 \mathrm{~kg}$, the longer the working time will be according to the volume but not too far of the maximum mixing time is 15 minutes. 


\subsection{Performance test}

After 15 minutes of the mixing process, the coffee beans which were initially dry after being mixed with the bio ghally fermented liquid, the texture of the coffee beans became wet, and the colour of the coffee beans which were originally pure white became brownish. This shows that the stages of the mixing process have been completed and the mixer can be turned off and the coffee beans are removed through the output channel and then the coffee beans will be stored in a tube and then closed tightly and the next stage of the process will be carried out.

\section{Results and Discussion}

The coffee bean mixer with bio ghally fermented liquid was designed to have several components that are interconnected with one another (Figure 3). The components of this coffee bean mixer consist of the main frame, mixing tube, shaft, pulley and v-belt, electric motor, mini electric water pump, sprayer, fermented liquid tube, pillow block, and hopper. This coffee bean mixer works and can be operated continuously.
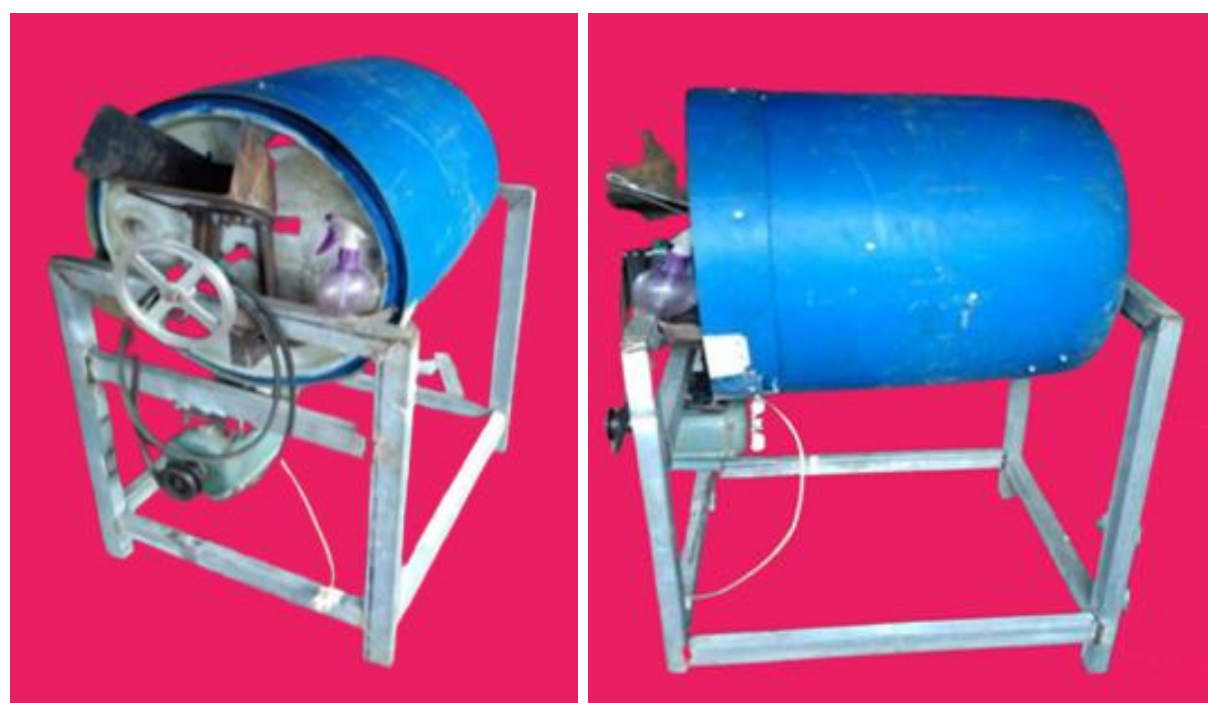

Figure 3. Coffee bean mixer

This coffee bean mixer was tested using coffee bean material with three tests, each test having a different volume of coffee bean weight, namely $10 \mathrm{~kg}, 15 \mathrm{~kg}$ and $25 \mathrm{~kg}$. Other components are prepared such as fermented liquid as much as 1.5 litres to 2.5 litres and are prepared such as starting the electric motor engine components and mini electric water pumps. The results of the performance test of this coffee bean mixing tool can be seen in the Table 1. 
Table 1. Test mixing coffee beans with liquid bio gally

\begin{tabular}{cccc}
\hline Descriptions & Test 1st & Test 2nd & Test 3rd \\
\hline Initial coffee weight $(\mathrm{kg})$ & 10 & 15 & 25 \\
Final coffee weight $(\mathrm{kg})$ & 11.3 & 16.1 & 26.3 \\
Mixing time & $73^{\prime} 33^{\prime \prime}$ & $12^{\prime}, 45^{\prime}$ & $15^{\prime} 17^{\prime \prime}$ \\
\hline
\end{tabular}

'Minutes; "seconds

According to Niranjan et al. (1994) that mixers for the food process and Agriculture industries classified into three categories; i.e. (1) dispersing and dissolution into liquids, (2) blending of particulate material, and (3) mixing of solid and liquids to form doughs, batters and pastes. Mixers are used extensively in the food products and agricultural processing for wide variety and different a specialized purposes. A coffee bean mixer does not into these three mixing categories and different with semisolid viscoelastic materials [Sun and Zhuo, 2018), but the proses are adding liquid to the coarse particles and mixing them evenly.

Mixers of processing agricultural and food products can be classified as either vessel type or pipe type. Vessel types are usually used in batch wise processes, whereas pipe type mixers are continuous (Niranjan et al., 1994). Vessel type mixers are fitted with rotors which agitate the material. The vessel are themselves self into periodic motion to induce agitation of the material. Pipe type mixers may be dynamic in which case contains rotor and stator arrangement, or may be static and contain stream splitters and reorientation element for laminar mixing or turbulent promoters for turbulent mixing (Niranjan et al., 1994). Whereas, this coffee bean mixer is combination of vessel and pipe type. The mixer consists of a vessel chamber where a helical screw is mounted on the central axle horizontally. This mixer similar with a fish feed mixer that consists of the following components; electric motor, transmission system, reduction gear, gear system, mixing chamber, outlet, support frame, mixer auger, chain and sprocket (Adebukola and Patrick, 2019), but the coffee mixing chamber is cylindrical.

This coffee bean mixer with bio ghally fermented liquid was designed to mix ghalkoff organic dry coffee with bio ghally fermented liquid. The working mechanism of this tool is by mixing dry organic Ghalkoff coffee beans with bio ghally fermented liquid in a mixing tube using a plastic drum. 
The initial stage is to enter dry coffee beans that have gone through various previous processes such as the separation process with the epidermis and sorting the size of the coffee beans and the broken coffee beans are put into the mixing tube through the hopper or input line. Dried coffee beans are mixed in a tube with bio ghally fermented liquid for 15 minutes at a time. In the mixing tube, the coffee beans are mixed with the bio ghally fermented liquid and stirred with the help of a helical screw made of plate iron. The helical screws mix the dry organic coffee beans with the bio ghally fermented liquid.

\section{Conclusions}

This coffee bean mixer with bio ghally fermented liquid was designed to mix ghalkoff organic dry coffee with bio ghally fermented liquid. The working mechanism of this tool is by mixing dry organic Ghalkoff coffee beans with bio ghally fermented liquid in a mixing tube using a plastic drum. The coffee bean mixing machine with a bet type bio ghally fermented liquid has a working capacity of $25 \mathrm{~kg}$ in 15 minutes 17 seconds with a $1 \mathrm{HP}$ electric motor.

\section{Acknowledgement}

The author would like to offer particular thanks to PT Gahlly Roelies Indonesia.

\section{References}

[1] Adebukola, A. A., and Patrick, O. A. 2019. Development and evaluation of a fish feed mixer. AgricEngInt: CIGR Journal 21:226-233.

[2] Cortez, J.G. and Menezez, H.C. 2000. Recent Developments in Brazilian Coffee Quality: New Processing Systems, Beverage Characteristics and Consumer Preferences. In: Sera T., Soccol C.R., Pandey A., Roussos S. (eds) Coffee Biotechnology and Quality. Springer, Dordrecht. https://doi.org/10.1007/978-94-017-1068-8_3.

[3] Martauli, E. D. 2018. Analysis of coffee production in Indonesia. Journal of Agribusiness Science 1: 112-20. 
[4] Mayrowani, H. 2013. Policy for providing postharvest technology for coffee and its development problems. Forum Penelitian Agro Ekonomi 3:31-49.

[5] Niranjan, K., Smith, D. L. O., Rielly, C. D., Lindley, J. A., and Phillips, V. R. 1994. Mixing Processes for Agricultural and Food Materials: Part 5, Review of Mixer Types. J. Agric. Engng Res. 59:154-161.

[6] Sembiring, N. B., Satriawan, I. K. and Tuningrat, I. A. M. 2015. The added value of processing arabica coffee in wet (west indischee bereding) and dry (ost indischee bereding) processing in Kintamani sub-district, Bangi. Jurnal Rekayasa dan Manajemen Agroindustri 3:61-72.

[7] Siregar, Z. A., Suthamihardja, R. T. M., and Susanty D. 2020. Characterization of Fermented Arabic Coffee (Coffea Arabica L.) with Lacto Acid Bacteria (Lactobacillus $S p$ ). Jurnal Sains Natural Universitas Nusa Bangsa 10:87-94.

[8] Sun, J., and Zhuo, D. P. 2019. Extrusion-Based Multiple Material Mixer Design in Food Printing 5:121-126.

[9] Swiranat, I. W., Mangku, I. G. P., and Rudianta, I. N. 2020. The effect of fermentation and drying method on the quality of Arabica coffe (Coffea arabica L.). Gema Agro $25: 150-158$.

[10] Thalia, T., Ersan, Delvitasari, F. and Maryanti. 2018. Fermentation effect of $S$. cerevisiaeon to Robusta coffee quality. Agritrop 18:60-77.

[11] Usman, D., Suprihadi, A. and Kusdiyantini, E. 2015. Robusta coffee (Coffea canephora) fermentation using lactic acid bacteria isolate from civet feces with long incubation time treatment. Jurnal Biologi 4:30-41. 